\title{
Turnover Intentions and its Drivers: A Study of Banking Sector
}

\author{
Malka Liaquat $^{\text {a }}$, Mohsin Ali ${ }^{\text {b }}$, Aisha Khursheed ${ }^{c}$, Qurat ul Ain ${ }^{\text {d }}$ \\ ${ }^{a}$ Assistant Professor, Institute of Management Science, The Women University, Multan, Pakistan \\ Email: malka.liaquat@wum.edu.pk \\ ${ }^{\mathrm{b}}$ Lecturer, Management Sciences, National University of Modern Languages, Multan, Pakistan \\ Email: mohsin.ali@numl.edu.pk \\ ${ }^{\mathrm{c}}$ Lecturer, Business Administration, University of Education, Multan, Pakistan \\ ${ }^{\mathrm{d}}$ Lecturer, Business Administration, Foundation University Rawalpindi, Pakistan
}

\begin{tabular}{ll}
\hline ARTICLE DETAILS & ABSTRACT \\
\hline History: & The current study aims to explore factors which influence perceptions of \\
Accepted o7 March 2021 & $\begin{array}{l}\text { employees and shape their intentions to leave the organization. It } \\
\text { Available Online March } 2021\end{array}$ \\
& $\begin{array}{l}\text { utilizes psychological factors that serve as baseline for turnover } \\
\text { evaluated through structural equation modeling in AMOS. Results reveal }\end{array}$ \\
\hline Keywords: & interesting insights identifying intrinsic rewards as significant factor in \\
Intrinsic Rewards, Psychological & countering the turnover intentions whereas, justice perception and \\
Contract, Informational justice, & organizational support do not play direct role in shaping employees \\
Perceived Organizational & perceptions. Results carry managerial and practical guidelines that can \\
Support, Turnover Intentions & be usefulfor organizations for creating a strategic taskforce.
\end{tabular}

JEL Classification:

J32, J39, D63, D23, D29

DOI: $10.47067 /$ reads.v7i1.321

(C) 2021 The authors. Published by SPCRD Global Publishing. This is an open access article under the Creative Commons Attribution-

NonCommercial 4.0

Corresponding author's email address: malka.liaquat@wum.edu.pk

\section{Introduction}

(Devi and Pojitha, 2012) state that organizations use its human resource as an important tool to compete and win from its competitors. According to Becker \& Gerhart (1996), organization is about not only technology, infrastructure or machinery rather it is about its people, such strategic assets are not easily tradeable, and organizations should be conscious towards these resources as they limited and not conveniently accessible. (Budhwar \& Debrah, 2009) identified that remarkable progress has been made in the realm of human resource; however, it still faces different challenges in different economies and needs to be explored.

(Santhanam, Kamalanabhan, Dyaram, \& Ziegler, 2017) state how employees attitude is reflected towards its organizations comes through its subjective assessment of its organization. If an employee perceive the organization is not supporting not being fair in its processes can built a negative feeling 


\section{Review of Economics and Development Studies, Vol. 7 (1) 2021, 51-61}

towards it organization and might built intentions to quit. Turnover casts huge impacts on organizations both in terms of money and knowledge resource. (Hinkin \& Tracey, 20oo) claim " Turnover is costly" , further (Holtom, Mitchell, Lee, \& Eberly, 2008) quote that irrespective of economic situation the shortages or labor is a critical factor for industries all over the globe, therefore retaining knowledge taskforce or key employees is critical for organizational success. In an recent study conducted by (Khan, Khan, Mohmand, \& Misbah, 2020) affirm that turnover can influence firm's performance and productivity status. Rewards especially internal rewards is one of such factor, which contours employees thinking patterns.

Employees evaluates the way its organization acts/reacts, based on which their perceptions are shaped. How much organization care about its people or support them is covered in reign of perceived organization support (POS). (Kurtessis et al., 2017) proposes that organizational support lends to multiples outcomes that can be both productive and counterproductive in nature such organizational citizenship behavior, performance.

Another factor, which contributes in shaping employees perceptions and attitudes, is how fairly employees are being treated in the organization, a phenomena often known as organization justice. It is professed as fairness perception (Byrne and Cropanzano, 2001) that categorizes employee's behavior in organization. It has been labeled as a multidimensional phenomenon with four sub-types as distributive, procedural and interactional where these all are related with employee's perceived perception about fairness in terms of resources allocation, decision process and behaviors of peers and supervisor in the organization (Yadav \& Rangnekar, 2015).

(Stumpf, Tymon, Favorito, \& Smith, 2013) points out that by creating and giving value to employees, organizations can achieve greater goals of engagement and retention, thus keeps its strategic resources to itself. Studies (Liaquat \& Zahra, 2015; Restubog, Zagenczyk, Bordia, Bordia, \& Chapman, 2015) advocate that organizational factors such as breach of psychological contract (PC) plays a substantial role in influencing and shaping employees behaviors and reaction towards organizational processes and phenomenon and has received less attention in literature. (Santhanam et al., 2017) also endorse, to study psychological breach and its influence on turnover intentions in other context and industries.

All these perspectives are important in predicting employee intention to leave the organization. Studies (James, 2020; Nawaz, Siddiqui, Rasheed, \& Iqbal, 2019) conducted in service sector i.e. higher education and hotel industry on turnover advises to further explore factors that contributes towards involving different geographic boundaries and aspects. The current study explores the psychological and organizational perspectives, which can influence an employee's attitude towards its organization. Thus, it aims to address how inter-organizational factors influence employee turnover intentions via psychological contract breach as a mediator in Pakistani banking sector, exploring new avenues from both academic and managerial perspectives.

\section{Literature Review and Hypothesis}

\subsection{Intrinsic Rewards and Turnover Intentions}

Rewards play an imperative role in an organization shaping the mental make-up of an individual. Barnard (1938) proposed that various forms of rewards that employees receives serves as a base for evaluation its work's contextual aspects. On the premises of SET, if employees are rewarded by its organization, they reciprocate it favorably through their positive attitudinal outcomes and responses (Blau, 1964; Haar \& Spell, 2004). Rewards are categorized as social, extrinsic and intrinsic in nature 


\section{Review of Economics and Development Studies, Vol. 7 (1) 2021, 51-61}

(Elizur, 1984) where social is about interpersonal, extrinsic is tangible benefits such as money whereas autonomy in task comes in intangible benefits summed up intrinsic rewards.

Previous studies (Pfeffer, 1994; Smith and Tyler, 1997; Hallock, 2002) emphasize the notion to develop and promote intrinsic rewards as it lends a sense of identification and belonging of an employee with its organization, it can promote and maximize the knowledge sharing ability and would lead to development of professional and ethical workplace. So employee's perception not only the cognitive patterns rather emotional side is influenced how organizations rewards him/her intrinsically. Therefore, it is stated that:

H1: Intrinsic rewards have a relationship with turnover intentions.

\subsection{Perceived Organizational Support and Turnover Intentions:}

POS is the, "overall extent to which employees believe that their organization values their contribution and cares about their well-being” (Eisenberger, Huntington, Hutchison, \& Sowa, 1986). Employees always look at its organizations for support in terms of information, fair procedures, and emotional aspects and do evaluate how organizations assess its hard work and contributions.

According to (Levinson, 2009) by building exchange relationship of cordial nature between employee and its employers, organizations can get desired and favorable results. (Eisenberger et al., 1986) quotes organization's treatment with its employees can profound effects on building cognitive and emotional interpretations. They further state that organizations support in form of appreciation and recognition also lends a supporting role for its employees. (Maertz, Griffeth, Campbell, \& Allen, 2007) state that when employees perceptions is strongly influenced through POS it creates a stance of obligation in employees to reciprocate through remaining in the organization. Thereby, it can be stated that:

H2: POS has relation with TOI

\subsubsection{POS, Psychological Breach of Contract and Turnover Intentions:}

Another term, which comes in mind on basis of employee's interpretations of exchanges with its organization, is of psychological contract. Rousseau (1989) state it as "an individual's beliefs regarding the terms of conditions of a reciprocal exchange agreement between the focal person and another party". In another work (Rousseau, 2001) explains that PC is multi-stage phenomenon, first it is a preconceived cognitive conceptualization which is general in its nature such as professional norms. However, at later stage it becomes an ingrained notion that stabilizes and shapes psychological makeup of employees. (Armeli, Eisenberger, Fasolo, \& Lynch, 1998; Pohl, Bertrand, \& Ergen, 2016) quote that how organizations support its employees helps employees to build up its confidence in the organization and it helps to strengthen its obligation towards its organizations. The Later state that in context of social exchange theory, it is the reciprocity principles according which employees finds himself/herself more prone and liable to organization if it look after his/her interests. It is thus hypothesized that:

H2a: POS has relation with breach of PC

Employees evaluates organizational policies in comparison with tasks and activities carried out by him/her and when it finds a failure it is termed as psychological contract breach (Eckerd, Hill, Boyer, Donohue, \& Ward, 2013) who further state that it is very important to understand the consequences these failure would have on employee's behavior. (Pohl et al., 2016) state that both POS and PC are measures of attitude states and breach of psychological contract can lead to negative outcomes. Thus, if organizations upkeeps with its people, it forms an unexplained binding, which can help to, give 


\section{Review of Economics and Development Studies, Vol. 7 (1) 2021, 51-61}

negatives intentions such as turnover. Therefore, it can be hypothesized that:

H2b: Breach of Psychological Contract mediates between POS and TOI

\subsection{Informational Justice and Turnover Intentions:}

According to Miller (2001), sense of respect and dignity is created when employees see being treated fairly. (LePine et al., 2002: Colquitt et al., 2001) further stated that unfair treatment can leads to counterproductive behaviors and distort the inherent belief of rightness. Halbesleben and Demerouti (2005), linked unfair treatment with developing of involuntary withdrawal that can worsen into turnover. Further (Murphy and Vives, 2013) in their work also observed that if employees feel being treated unfairly on continuous basis, they would replicate these behaviors on their subordinates thus creating a multiplying effect which eventually reaches to organization's lower level.

In another study (Hussain \& Khan, 2019) state that it is even plausible to state that this influence is not limited to employees rather it would customers as well. Adding more he stated that when organizations are in phase of change such downsizing or making profit it often hides information from its employees which generates negative feelings towards the organization. So if employees are perceive that they are not provided accurate information or details it can make them leave their organization. On basis of this, it can be stated that:

H3: Informational justice has relation with turnover intention.

\subsubsection{Informational Justice, Psychological Breach and Turnover Intentions}

Justice perception carry strong psychological effects on employee behaviors, according to (Rosen, Chang, Johnson, \& Levy, 2009) psychological contract yield out as a possible outcome of justice perception, as it is result of cognitive analysis and evaluations of employee about its workplace. Thus if an employee perceive that organization is violating his/her rights it leading towards breach of PC. Thus, H2a: Informational justices has a relationship with breach of PC

Many scholars i.e. (Estreder, Rigotti, Tomás, \& Ramos, 2020) tried to describe psychological contract and several of those descriptions repeated common principles, including goals, values, reciprocity, and responsibilities. The definition used for this study states psychological contract as a belief of personnel about a joint responsibility amongst the personnel and their organization (Rousseau, 1989). Scholars concluded that it has an arbitrary nature; because being of contingent on the opinion of individual as to what responsibilities, the company will meet (Bellou, 2009; Rousseau, 1989; Rousseau, 1995). Personnel, who face violation of their psychological contract, may experience various responses that may range from attitudinal responses to responses towards organization. (Kickul \& Lester, 2001). Suazo (2009) was amongst first amongst researchers who discovered an inverse association amongst the breach of psychological contract and perceived support for the organization.

H3b: Breach of PC mediates between TOI and IJ

\subsection{Breach of Psychological Contract and Turnover Intention}

Numerous institutions now recognize the bottom-line impact on quality employee retention. When the workers are happy at work, they do not consider quitting it. Holding quality workers actually adds to efficiency and morale, thus reducing the direct and related attrition costs. Employee retention can be increased on by using these steps: 1) job analysis audit, 2) job-designed assessments, 3) professional development, 4) relationship between manager and employee, 5) competitive \& equitable pay system, and 6) succession planning. Employee development raises a positive contribution to an organization's performance. In reality, well-qualified employees can attain the goals in time, which extend their expertise and knowledge. Akanbi (2005) emphasized that an employee is required to 
receive a reward once task is complete.

H4: Breach of psychological contract has a relationship with Turnover intentions

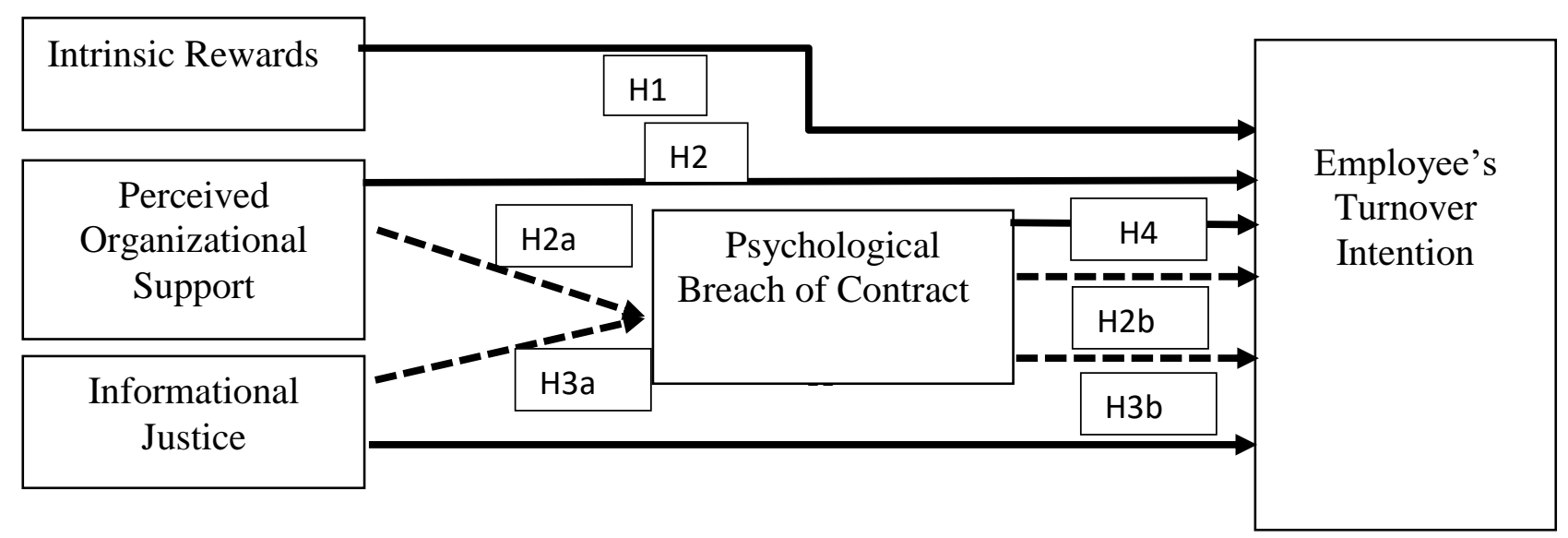

Figure 1: Framework for conceptualization

\section{Methodology}

\subsection{Sampling and Data Collection}

This research is targeting commercial bank's employees form southern region of Punjab. Commercial banking organizations include, HBL, Askari bank ltd., MCB bank ltd., Soneri bank ltd, ABL, UBL, Zarai Tarakiyati bank, Bank Al Habib ltd, Silk and Islamic bank ltd. For the purpose of data collection Officers from Grade OGIII to OGI were touched. Non-probability purposive sampling technique has been used for the purpose of data sampling. Lunchtime was selected to contact officers of banks to ensure their productive response. Officers were informed about the scope as well as significance of the present study and guaranteed that their confidentiality will be ensured in order to ensure that they may become able to respond authentically while filling items of questionnaire. Size of the sample is quantity of units of sample which are selected from the nominated area. Sample based on 404 respondents were acquired from the nominated area.

\subsection{Variables operationalization}

Scales for current study is adopted from prior studies and measured on 5-point likert scale from strongly disagree to strongly agree range.

\subsubsection{Intrinsic Reward:}

Present study used Minnesota Satisfaction Questionnaire (MSQ) short form documented by Eisenberger et al., (1986) consisting of 12-items.

\subsubsection{Perceived Organizational Support:}

A condensed scale of eight items designed by Eisenberger et al., (1986) is employed to quantify this construct, which gauged participant's believe about their organization that whether it value contributions made by them and care for their well-being.

\subsubsection{Informational Justice}

The study under consideration used the 3-item questioner designed by Niehoff and Moorman (1993) for measuring informational justice's construct.

\subsubsection{Psychological Contract Breach}


It refers to perception of an employee that one or more responsibilities of the company are not met (Morrison \& Robinson, 1997). This has been operationalized by using the scale of 9-items designed by by Morrison \& Robinson (1997).

\subsubsection{Turnover Intentions}

This study has used fifteen item scale designed by Steers \& Porter (1982) for measuring turnover intentions.

\section{Results}

\subsection{Demographics within sample}

Age, gender, educational qualification and, experience has been used to measure the demographic component for each respondent. The larger part of the study's respondents hold postgraduate qualifications i.e. 94.3\%. The demographic profile acquired further confirms that the majority of the sample i.e. $61.8 \%$ belongs to mature aged group of employees ranging age from 31 years and above. However, a relatively smaller age group i.e. $38.2 \%$ also works and their ages range between 20 years to 30 years. In addition to that table 4.1 also reports experience at work of workers working in the sample banks. Results demonstrate that astonishingly major portion about 85.9\% of the sample comprised of people having lesser experience i.e. one year to ten years, whereas merely $14.1 \%$ of employees have service experience above 16years.

\subsection{Measurement of Normality}

Before moving towards SEM, a basic check to continue with is the speculation of ordinariness. Both kurtosis and skewness with high nature are systematic of non-ordinariness of data. Following tables exhibits that data is typical as the estimations of Kurtosis and Skewness the two lies in as far as possible regard which is $<3$ and $<0$ and which gave a chime formed outline showing that data isn't encountering any issue of ordinariness.

Table 1: Descriptive Statistics of Perceived Organizational Support, Psychological breach and Turnover Intentions

\begin{tabular}{|l|c|c|c|c|c|c|}
\hline \multirow{2}{*}{} & N & Mean & \multicolumn{2}{c|}{ Skewness } & \multicolumn{2}{c|}{ Kurtosis } \\
\cline { 2 - 7 } & Statistic & Statistic & Statistic & Std. Error & Statistic & Std. Error \\
\hline COMP_POS & 404 & 3.7101 & -.111 & .121 & -.144 & .242 \\
\hline COMP_PCB & 404 & 3.5492 & -.186 & .121 & -.618 & .242 \\
\hline COMP_IJ & 404 & 3.9497 & -.303 & .121 & .431 & .242 \\
\hline COMP_TOI & 404 & 3.6734 & -.329 & .121 & -.242 & .242 \\
\hline Valid N (listwise) & 404 & & & & & \\
\hline
\end{tabular}

\subsection{Bivariate Correlation:}

Results of correlations among the constructs are show in table 2 showing that a positive connection of ward constructs (Turnover Intention) with every single diverse variable both autonomous and go between. Moreover, there also exists positive relationship among every single distinctive variable as well. 
Review of Economics and Development Studies, Vol. 7 (1) 2021, 51-61

Table 2: Correlations Analysis

\begin{tabular}{|c|c|c|c|c|c|c|}
\hline & & COMP_IR & COMP_POS & COMP_PCB & COMP_IJ & COMP_TOI \\
\hline \multirow{3}{*}{ COMP_IR } & Pearson Correlation & & $.467^{* *}$ & $391^{* *}$ & $.264^{* \star}$ & $.455^{* *}$ \\
\hline & Sig. (2-tailed) & & .000 & .000 & .000 & .000 \\
\hline & $\mathrm{N}$ & 404 & 404 & 404 & 404 & 404 \\
\hline \multirow{3}{*}{ COMP_POS } & Pearson Correlation & $.467^{* *}$ & 1 & $.477^{* *}$ & $.307^{* *}$ & $.405^{* *}$ \\
\hline & Sig. (2-tailed) & .000 & & .000 & .000 & .000 \\
\hline & $\mathrm{N}$ & 404 & 404 & 404 & 404 & 404 \\
\hline \multirow{3}{*}{ COMP_PCB } & Pearson Correlation & $.391^{* *}$ & $.477^{* *}$ & 0.704 & $.355^{* *}$ & $421^{* *}$ \\
\hline & Sig. (2-tailed) & .000 & .000 & & .000 & .000 \\
\hline & $\mathrm{N}$ & 404 & 404 & 404 & 404 & 404 \\
\hline \multirow{3}{*}{ COMP_IJ } & Pearson Correlation & $.264^{* *}$ & $.307^{* *}$ & $.355^{* *}$ & 1 & $.226^{* *}$ \\
\hline & Sig. (2-tailed) & .000 & .000 & .000 & & .000 \\
\hline & $\mathrm{N}$ & 404 & 404 & 404 & 404 & 404 \\
\hline \multirow{3}{*}{ COMP_TOI } & Pearson Correlation & $.455^{* *}$ & $.405^{* *}$ & $.421^{* *}$ & $.226^{* *}$ & 1 \\
\hline & Sig. (2-tailed) & .000 & .000 & .000 & .000 & \\
\hline & $\mathrm{N}$ & 404 & 404 & 404 & 404 & 404 \\
\hline
\end{tabular}

\subsection{Analysis of Hypothesis:}

Table shows the immediate and round about relationship among the autonomous just as reliant factors with and without mediator.

Table 3: Hypothesis Results

\begin{tabular}{|c|c|c|}
\hline Relationship & R.W / P - Value & Result \\
\hline H1 -- IR-TOI & $\begin{array}{c}\text { R.W }=0.249 \\
\text { P-Value }=0.000\end{array}$ & Accepted \\
\hline H2 -- POS-TOI & $\begin{array}{c}\text { R.W }=0.240 \\
\text { P-Value }=0.126\end{array}$ & Rejected \\
\hline H2a --POS-PCB & $\begin{array}{c}\mathrm{R} . \mathrm{W}=0.213 \\
\text { P-Value }=\mathbf{0 . 0 0 0}\end{array}$ & Rejected \\
\hline H2b --POS-PCB-TOI & $\begin{array}{c}\text { R.W }=0.213 \\
\text { P-Value }=\mathbf{0 . 0 0 0}\end{array}$ & Accepted \\
\hline H3 -IJ---TOI & $\begin{array}{c}\mathrm{R} . \mathrm{W}=-0.213 \\
\text { P-Value }=0.124\end{array}$ & Rejected \\
\hline Нза---IJ--PCB & $\begin{array}{c}\mathrm{R} . \mathrm{W}=0.251 \\
\mathrm{P}-\text { Value }=0.001\end{array}$ & Accepted \\
\hline H3b---IJ--PCB-TOI & $\begin{array}{c}\text { R.W }=0.157 \\
P-\text { Value }=0.001\end{array}$ & Accepted \\
\hline H4--- PCB-TOI & $\begin{array}{c}\text { R.W }=0.254 \\
\text { P. Value }=0.000\end{array}$ & Accepted \\
\hline
\end{tabular}

RW== Regression Weight 


\section{Review of Economics and Development Studies, Vol. 7 (1) 2021, 51-61}

\section{Discussion}

This part focuses upon the results of analysis and studies which align with these results. Estimation of regression weight 0.0249 and $\mathrm{p}$ value of 0.000 demonstrated that positive relationship exists between IR-TOI. The results supports $\mathrm{H} 1$, stating that rewards especially intrinsic ones successfully molds employee's behaviors and expectations to leave an occupation or remain in the activity. Thus an employee's will to exist or stay in an organization is determined through rewards being given (Yukl, 2002; Walumbwa and Chad, 2011). In case of POS and TOI, analysis reports that there is no significant relationship as regression weight is 0.24 and p-value is 0.126 . It can be inferred that employees while making intention to leave do not take organizational support as a significant factor in influencing there decision. One of the reason of this insignificant relationship can be that in banking sector more less support provided is of similar nature thus that cannot be contribute to perceive any differential effect on employees and lies in line with study of (Mathieu \& zajac, 1990) stating employee mental model is not influenced by organizational support. In case of mediational relationship, the result of regression weight 0.213 and p-value 0.000 affirms H2a, showing PCB fully mediates between POS and TOI. This lies in reference with previous studies (Bass 1985; Judge et al, 2001) stating that if support provided by organization is violated it breaks the psychological bonding of employee with its organization, therefore, leading to TOI.

Results reveal that there is significant but negative relationship between IJ and TOI with a $\mathrm{p}$ value of 0.000 and regression weight -0.213, which indicates that if there employees are perceive that they are being treated fairly it will reduce their intentions to leave the organizations. In case of IJ and Breach of PC $(\mathrm{R} . \mathrm{W}=0.251, \mathrm{P}-$ Value $=0.001)$ shows positive and significant relationship thus, if employees perceive lack of fair information it reciprocates towards breaking of their psychological bondage with the organization which lies in endorsement of study of (De Ruiter, Schalk, Schaveling, \& Van Gelder, 2017) claiming that if employees observes lack of supervisory IJ it can strengthen one's breach of PC. With reference to mediation, breach of PC also plays significant role with p-value of o.001, between IJ and TOI, thus a partial mediation occurs showing that Psychological Contract Breach incorporates all achievements that a representative accepts to be granted by the firm leading to acceptance of $\mathrm{H} 3 \mathrm{~b}$. Analysis reveal that a relationship exist between PCB and TOI with p-estimation of 0.000 and regression weight of 0.254 , thus if employees perceive that psychological contract is violated than employees will be prone to turnover intentions thereby will leave organization which aligns with H4 proposed.

\section{Managerial Implications}

The investigation is fascinating in its type as it focuses on constructs that classify an individual's obligations and connections with each other and with one's organization. This investigation provides accommodating encounters for administrative ramifications to be carried out in an organization. The study entails following implications for the managers:

- Management can design attractive financial frameworks which ensure the smooth functioning of employees.

- Management should provide fair information to its people, which can be beneficial for gaining employee's trust and function more effectively.

- Another sound administrative commitment is that, if organization can give its employees legitimate prizes and recognition it would lead to fruitful result.

\section{Limitations \& Future Directions}

The current study has attempted to explore the effects carefully; however still there are areas 


\section{Review of Economics and Development Studies, Vol. 7 (1) 2021, 51-61}

that can be worked upon:

- Purposive sampling has been used in this study which is non-probability technique, by applying probability technique, results can be more generalizable.

- The research has been carried out with cross-sectional data, whereas longitudinal data can provide better insight.

- The current work has focused upon banking sector, the results can be further validated by taking in view from other financial institutions or NGO.

Despite the fact that the investigation inadequacies in above zones, still it displays and regarded and effective energetic about relationship among the factors alongside which the examination additionally approves the structure created by giving record of how to improve the representative profitability.

\section{Conclusion}

The study attempted to explore the psychological perspective of employees that makes them built up intentions to leave. The model is subjected to testing through structural equation modelling through AMOS taking data form banking sector. Results provide useful baseline that employees do get influenced with how much value, reward and fair treatment is provided, which if not fulfilled leads to negative feelings towards the organization. As per notion of Social exchange theory (Blau, 1964), employees would reciprocate with what they get from organization. Employees would feel themselves to be liable towards its organization. However, if there is lack of recognition, justice and support, an employee will choose to leave the organization.

\section{References}

Adams, J. S. (1965). Inequity in Social Exchange. In L. Berkowitz (Ed.), Advances in Experimental Social Psychology, New York: Academic Press.

Armeli, S., Eisenberger, R., Fasolo, P., \& Lynch, P. (1998). Perceived organizational support and police performance: The moderating influence of socioemotional needs. Journal of Applied psychology, 83(2), 288.

Becker, B. and Gerhart, B. (1996). The Impact of Human Resource Management on Organizational Performance: Progress and Prospects. Academy of Management Journal, 39(4), 779-801.

Bellou, V. (2009). Profiling the desirable psychological contract for different groups of employees: Evidence from Greece. The International Journal of Human Resource Management, 20, 810-830. doi: 10.1080/09585190902770711Blau, P. M. (1964). Social exchange theory. Retrieved September, 3(2007), 62.

Budhwar, P., \& Debrah, Y. A. (2009). Future research on human resource management systems in Asia. Asia Pacific Journal of Management, 26(2), 197.

Buss, A. H. (1983). Social rewards and personality. Journal of Personality and Social Psychology, $44,553-563$.

Colquitt, Jason A. (2001). On the dimensionality of organizational justice: A construct validation of a measure. Journal of Applied Psychology 86 (3), pp. 425-445. doi: 10.1037//oo219010.86.3.386

Devi, V. R., and Poojitha, V. (2012). HRD-A Source for Competitive Advantage. Review of Research, 1(7), 56-72.

Deci, E. L. (1971). Effects of Externally Mediated Rewards on Intrinsic Motivation. The Journal of Personality and Social Psychology, 18(1), 105-115.De Ruiter, M., Schalk, R., Schaveling, J., \& Van Gelder, D. (2017). Psychological contract breach in the anticipatory stage of change: 


\section{Review of Economics and Development Studies, Vol. 7 (1) 2021, 51-61}

Employee responses and the moderating role of supervisory informational justice. The Journal of Applied Behavioral Science, 53(1), 66-88.

Eckerd, S., Hill, J., Boyer, K. K., Donohue, K., \& Ward, P. T. (2013). The relative impact of attribute, severity, and timing of psychological contract breach on behavioral and attitudinal outcomes. Journal of Operations Management, 31(7-8), 567-578.

Eisenberger, R., Huntington, R., Hutchison, S., \& Sowa, D. (1986). Perceived organizational support. Journal of Applied psychology, 71(3), 500.

Elizur, D. (1984). Facets of work values: A structural analysis of work outcomes. Journal of Applied psychology, 69(3), 379.

Gould, S. (1979). An equity-exchange model of organizational involvement. Academy of Management Review, 4, 53-62.

Estreder, Y., Rigotti, T., Tomás, I., \& Ramos, J. (2020). Psychological contract and organizational justice: the role of normative contract. Employee Relations: The International Journal, 42(1), 17-34. doi:10.1108/ER-02-2018-0039

Haar, J. M., \& Spell, C. S. (2004). Programme knowledge and value of work-family practices and organizational commitment. The International Journal of Human Resource Management, 15(6), 1040-1055.

Hinkin, T. R., \& Tracey, J. B. (2000). The cost of turnover: Putting a price on the learning curve. Cornell hotel and restaurant administration quarterly, 41(3), 14-21.

Holtom, B. C., Mitchell, T. R., Lee, T. W., \& Eberly, M. B. (2008). 5 turnover and retention research: a glance at the past, a closer review of the present, and a venture into the future. The Academy of Management Annals, 2(1), 231-274.

Hussain, M., \& Khan, M. S. (2019). Organizational justice and turnover intentions: probing the Pakistani print media sector. Evidence-based HRM: a Global Forum for Empirical Scholarship, 7(2), 180-197. doi:10.1108/ebhrm-04-2018-0030

James, G. L. (2020). Relationship Between Intrinsic Job Satisfaction, Extrinsic Job Satisfaction, and Turnover Intentions in Luxury Hotels.

Judge, T. A., Thoresen, C. J., Bono, J. E., and Patton, G. K. (2001). The Job Satisfaction- Job Performance Relationship: A Qualitative and Quantitative Review. Psychological Bulletin, 127, 376-407.Khan, S., Khan, M. H., Mohmand, A. M., \& Misbah, S. (2020). Impact of HR Practices on Employee Turnover and Job Satisfaction: Evidence from Pakistani Universities. Review of Economics and Development Studies, 6(3), 607-624.

Kickul, J. \& Lester, S. W. (2001). Broken promises: Equity sensitivity as a moderator between psychological contract breach and employee attitudes and behavior. Journal of Business and Psychology, 16, 191-217. doi: 0889-3268/01/1200-0191Kurtessis, J. N., Eisenberger, R., Ford, M. T., Buffardi, L. C., Stewart, K. A., \& Adis, C. S. (2017). Perceived organizational support: A meta-analytic evaluation of organizational support theory. Journal of Management, 43(6), 1854-1884.

Levinson, H. (2009). Reciprocation: The relationship between man and organization.

Liaquat, M., \& Zahra, S. (2015). Justice perception and turnover Intentions with moderating role of locus of control. European Academic Research, 2(12).

Maertz, C. P., Griffeth, R. W., Campbell, N. S., \& Allen, D. G. (2007). The effects of perceived organizational support and perceived supervisor support on employee turnover. Journal of Organizational Behavior, 28(8), 1059-1075. doi:10.1002/job.472

Malone, T. W. (1981). Toward a theory of intrinsically motivating instruction. Cognitive science, 5(4), 333-369.

Morrison, E. W., \& Robinson, S. L. (1997). When Employees Feel Betrayed: A Model of How Psychological Contract Violation Develops. The Academy of Management Review, 22(1), 


\section{Review of Economics and Development Studies, Vol. 7 (1) 2021, 51-61}

226-256.

Mowday, R.T., Porter, L.W., \& Steers, R.M. (1982). Employee- organizational linkages: The psychology of commitment, absenteeism, and turnover. New York: Academic Press.Nawaz, M. S., Siddiqui, S. H., Rasheed, R., \& Iqbal, S. M. J. (2019). Managing turnover intentions among faculty of higher education using human resource management and career growth practices. Review of Economics and Development Studies, 5(1), 109-124.

Niehoff, B. P. \& Moorman, R. H. (1993). Justice as a mediator of the relationship between methods of monitoring and organizational citizenship behavior. Academy of Management Journal, 6, 527-556.

Pohl, S., Bertrand, F., \& Ergen, C. (2016). Psychological contracts and their implications for job outcomes: A social exchange view. Military psychology, 28(6), 406-417.

Restubog, S. L. D., Zagenczyk, T. J., Bordia, P., Bordia, S., \& Chapman, G. J. (2015). If you wrong us, shall we not revenge? Moderating roles of self-control and perceived aggressive work culture in predicting responses to psychological contract breach. Journal of Management, 41(4), 1132-1154.

Rosen, C. C., Chang, C.-H., Johnson, R. E., \& Levy, P. E. (2009). Perceptions of the organizational context and psychological contract breach: Assessing competing perspectives. Organizational Behavior and Human Decision Processes, 108(2), 202-217.

Rousseau, D. M. (2001). Schema, promise and mutuality: The building blocks of the psychological contract. Journal of occupational and organizational psychology, 74(4), 511-541.

Rousseau, D. M. (1995). Psychological contracts in organizations. Thousand Oaks, CA: Sage Publications, IncRousseau, D.M. (1989). Psychological and implied contracts in organizations. Employee Rights and Responsibilities Journal, 2, 121-139.Ryan, R. M., \& Deci, E. L. (2000). Intrinsic and Extrinsic Motivations: Classic Definitions and New Directions. Contemporary Educational Psychology, 25(1), 54-67.

Santhanam, N., Kamalanabhan, T. J., Dyaram, L., \& Ziegler, H. (2017). Impact of human resource management practices on employee turnover intentions: Moderating role of psychological contract breach. Journal of Indian Business Research, 9(3), 212-228. doi:10.1108/JIBR-102016-0116

Stumpf, S. A., Tymon, W. G., Favorito, N., \& Smith, R. R. (2013). Employees and change initiatives: intrinsic rewards and feeling valued. Journal of Business Strategy, 34(2), 21-29. doi:10.1108/02756661311310422

Suazo, M. M. (2009). The mediating role of psychological contract violation on relations between psychological contract breach and work-related attitudes and behaviors. Journal of Managerial Psychology, 24, 136-16o. doi: 10.1108/02683940910928856

Yadav, M., \& Rangnekar, S. (2015). Supervisory support and organizational citizenship behavior. Paper presented at the Evidence-Based HRM: A Global Forum for Empirical Scholarship.

Yadav, M., \& Rangnekar, S. (2015). Supervisory support and organizational citizenship behavior. Paper presented at the Evidence-based HRM: a Global Forum for Empirical Scholarship.

Zhao, H., Wayne, S. J., Glibkowski, B. C., \& Bravo, J. (2007). The impact of psychological contract breach on work-related outcomes: A meta-analysis. Personnel Psychology, 6o, 647-68o. 